\title{
Employing Discourse, Language and Television Media to Reconstruct the Image of Islam: A Case Study of Malaysia
}

\author{
Airil Haimi Mohd Adnan \\ Faculty of Arts, University of Auckland \\ 717 Fisher Int'l Building, 18 Waterloo Quadrant, Auckland, New Zealand \\ Tel: 62-22-610-3169_E-mail: airil@teechconsult.com
}

This research is sanctioned and supported by the Islamic Development Department of Malaysia under the Prime Minister's Office.

\begin{abstract}
Religion and mass media have always had an uneasy relationship as both spheres seem to have contradictory aims and objectives. Employing a discourse driven textual analysis of script excerpts from a contemporary religious program in Malaysia and in-depth personal interview data from key production personnel of the said television program, this research effort analyzes how modern electronic media concept, content and language medium were used to try to present a contemporary, forward looking, 'popular' view of Islam in a moderate, modern Muslim majority country. The results of this research effort point to the possibility of using electronic media not merely as a vehicle for blunt religious indoctrination, but as a means to disseminate positive universal human values across linguistic, racial, religious and social differences that in turn will help in strengthening multicultural, multi-religious nations - as in the case of Malaysia.
\end{abstract}

Keywords: Discourse analysis, Humanities, Malaysia, Popular Islam, Television media

\section{Introduction: 'Reflections' as a contemporary and popular image of Islam}

'Reflections' was a 30 minutes (24-26 minutes actual production run) television program produced by the Islamic Development Department of Malaysia (JAKIM) under the Prime Minister of Malaysia's Office together with the Malaysian Official Radio and Television Broadcasters (Radio dan Televisyen Malaysia or RTM). JAKIM was given several institutional objectives by the government, for example to implement programs for the advancement of the ummah (or Muslim community at large) and the inculcation of universal Islamic values across religions, to evaluate Islamic affairs programs that are carried out in the country, and also to act as a compiler, disseminator and centre of information on all Islamic affairs (see JAKIM, 2006). The first season of Reflections consisting 10 episodes altogether was successfully aired in 2005-2006. This was followed by 10 more episodes for the second season that went on air in 2006-2007.

The researcher was linked to this program as its external concept consultant and as the sole presenter of this television program. Reflections were divided into three main segments. The first covers the activities of local youths at public universities, mainly involving Muslim youths. The second segment is a topical discussion segment on Islam and the relation of the religion to science and scientific knowledge. The closing segment covers motivational words from Malaysian academics and expert motivators. The program was targeted towards the 13-17 age segment (upper and lower secondary students) and also the 18-24 (college and university students) and the general public who are proficient in the English language in Malaysia.

Unlike most electronic media productions by JAKIM, Reflections could be considered unique due to several factors. Firstly, it was delivered fully in English instead of the National Language, Bahasa Malaysia. This was a very significant choice to make as most Muslims in Malaysia are Muslims by birth due to their default race being Malay, the $60 \%$ majority population. For the Malay majority, the mother tongue is Bahasa Malaysia. Secondly, Reflections was presented not in the conservative and traditional sense of an Islamic program, at least not in the Malaysian context. The image projected on screen was of vibrant Muslim youths mingling with other races, the close link between Islam and knowledge, and how universal Islamic values could drive lives forward. Even the attire of the presenter was carefully chosen so as not to live up to the archetypal image of the Muslim cleric in a robe, sporting long beard and looking the business, as it were. 
All in all, Reflections from program concept, content to the medium of delivery was a conscious and concerted effort to present a contemporary and more popular image of Islam. Interestingly, this was also the very ideal espoused by the then Prime Minister of Malaysia, when he came into power. Prime Minister Abdullah Ahmad Badawi was adamant that Malaysian Muslims should strive to present a more open and popular image in the country and to the world through the mass media and by holding true to the teachings of this religion, but simultaneously incorporating modern technological advances into their daily lives and routine activities (Hamid, 2007).

\section{Situating the research: objectives, significance and review of literature}

\subsection{The objectives of this research}

Using the ideal construct of 'popular Islam' as a unifying theme, this research effort examined three main concerns. Firstly, how do we think about, plan and decide on a television program to present and represent Islam, and using stories from the lives of young Muslims in an interesting and contemporary manner? By achieving this objective, Malaysia should be able to transfer this knowledge to other countries or geographical settings where Muslims have access to the technology of television and television production. Secondly, to better help others (Muslims and non-Muslims alike) to understand how Islam and its teaching are actually related to modern life, what should we say or rather what information should we relay to the target audience using television as an electronic medium? This research objective has a practical value in that it could help generate a generic guideline on the preparation and presentation of television or even radio scripts, that are able to reflect and present a contemporary and popular face of Islam to the audience.

\subsection{The significance of this research}

This research is significant as it could help develop a multi-layered understanding of Islam as it relates to everyday lives and it could also be the basis to devise a framework on which future television programs should be produced so as to attract its target audience both Muslims and non-Muslims. This research could also have a positive social impact, as Malaysian Muslims can now be confident to change their mindsets and not view the electronic medium of television as bad or totally 'un-Islamic'. Another significance of this research is that the researcher was the actual concept advisor and television presenter of Reflections, who was able to provide an insider's view as it were, of this television program from beginning to end. Although this quasi-participant observation dimension heightens the possibility of researcher bias during the conception of research instruments and the actual data collection, it also added to the significance of this research within the central research theme of discourse, language, religion and the television media.

\subsection{Review of current literature in the humanities and social sciences related to this research}

The literature regarding 'popular Islam' and the electronic media could be grouped into two broad categories research that looks at how electronic media, television in particular, could be used to promote Islamic ideals and values to Muslims and non-Muslims in different geographical contexts; and another category of research that looks at the effects that the electronic media have made on the lives on Muslims, for better or for worse. Interestingly I should mention that the latter category of research articles and papers tend to have a rather negative and sometimes even bleak view of television as related to Islam as a religion and universal Islamic ideals and values. As such, this research project is a logical progression of these earlier works of researchers around the globe. I shall begin this subsection by looking at the first and second cluster of research before moving on to situate this current study within the Malaysian context.

Whine (2005) in his study of the ideological spread of Islam in the United Kingdom acknowledged that the electronic media, satellite television programs and popular Islamic websites in particular, have become one of the primary catalysts to help spread universal Islamic human values in that geographical context. This proposition is supported by the work of Norton (2003), who focused on new media and political reform in Muslim majority countries. In a different continent, Launay (1997) from his research effort in the Ivory Coast observed how television could be used as a direct medium to bring the peaceful and true message of Islam to Muslims and non-Muslims living in that setting. Indeed, contemporary media anthropologists like Lila Abu-Lughod (1993) who has conducted extensive media modelling and reception studies in the Middle East cautions researchers and members of the Muslim public to not automatically assume that the messages, in and of, so-called 'foreign' electronic media will automatically bring about a replacement of traditional Islamic values with Western ones that are usually viewed with suspicion and as incompatible with the Muslim way-of-life.

From a different dimension, Adamu's (2006) research findings are in direct opposition of Abu-Lughod's. Adamu is critical of the use of electronic media in the Muslim Hausa community of Nigeria due to the fact that, "the 
entertainment philosophy of [foreign] filmmakers found itself reproduced in Hausa videos and films in spite of the Shari'a [with] public display of erotica through the skimpy Western clothing of girls and their sexually suggestive dance routines" (p. 52). Adamu's views are also shared by Baig (2003), who wrote that "no one can have any doubt of the illegality of television in Islam. Television, as has been seen, is an embodiment of sin and immorality. Islam can never condone or permit an institution that plays havoc with the spiritual, mental, and moral development of mankind" (online). Timmerman's (2000) research on Turkish women in Belgium is another study that problematizes the medium of television as a possible negative source of influence on the lives of young Muslims around the globe (see Demographic Institute, 1999, for comparable findings in the neighbouring Muslim majority, Republic of Indonesia).

To exacerbate matters further, other researchers like Yamani (2003), Hussain (2000), Malashenko and Vale (2000), and Jones (1995), have generally observed how the electronic medium of television was used to spread negative news items on Islam and to paint a negative picture of Muslims, in different geographical settings. This has led to the so-called discourse of 'Islamophobia' especially in nation-states where Muslims are part of the minority group, for example in Denmark, France and Holland. Hussain's (2000) empirical research on the media representation of ethnic minority Muslims in Denmark found that the media in that country has played a negative role in the reproduction of a prejudiced discourse on ethnic minorities. In this process, Muslim minorities have been the primary victims due to the absence of social interaction between the majority population and minority groups in that developed nation.

\subsection{The current research niche - Malaysia}

The Government of Malaysia (2000) in planning for the future, is quite adamant that the electronic media and information communication technologies in this country should carry positive ideals and universal values based on the official national religion Islam, specifically "through skilfully crafted media campaigns through television and newspapers projecting stories of role models, etc; and khutbah [or sermon] the campaign should be a continuous exercise [for Malaysian Muslims]" (p. 164). Indeed Lorenzo-Dus (2009) believes that discourse, ideas and language could be shaped through the television media to project whatever the directors and producers wish to portray for better or for worse, a view supported by the empirical research efforts of Paietta (2005) who examined the portrayal of religious figures from Christianity in both film and television media.

In the Malaysian context, the reasoning and political motivation behind this move was that the family institution in this country is one of the primary locations for the dissemination of positive ideals and values, especially for the Muslim majority population and their hereditary adherence to Islam, and as many Muslim families in Malaysia have access to television and radio and now the Internet, Islamic ideals and values have been channelled to them for many years through Islamic religious programs (Camroux, 1996; Kling, 1995).

Therefore we could argue that policy-wise and demographically, Malaysia is an ideal testing ground for the development and production of Islamic-nuanced television programs (Roff, 1998) to spread and popularize a contemporary, intellectual and moderate vision of Islam as a catalyst for national peace, scientific inquiry and universal human rights. As this paper was written, several other government agencies are also looking into the possibility of using the medium of television as the vehicle for sharing universal Islamic values. As an example, the government funded and sanctioned Institute of Islamic Understanding Malaysia (IKIM) recently stated that "IKIM must carry out missionary activities using technology [...] If IKIM can seek more funds, it may consider venturing into television production where the programs will be slotted in the existing television channels. Or maybe one day, if it has the financial capacity and the government's approval, IKIM can set up its own television station and share the broadcasting equipment of other stations" (BERNAMA, 2007, online).

To conclude and restate the statement made earlier, an empirical and multi-layered study of the Reflections television program in the Malaysian context and socio-political climate is a project worthy of research, given that many (almost similar) academic efforts have already been undertaken by social scientists in different countries and at different points in history. This research should contribute to our practical understanding of how the electronic media, television in particular, could be used to promote universal ideals and human values to Muslims and relay a message of peace and promoting inter-ethnic and inter-religious understanding with non-Muslims, in the Malaysian context.

\section{Statement of problem and key research questions}

Currently, Muslims around the world are faced with many challenges as they continue to preserve their Islamic values and way-of-life. This has also led some Muslim quarters to reject modernity and development for fear that it would lead to decadence and the erosion of Islamic values whilst at the opposite end of the spectrum, to be seen as moderate liberals other Muslims have chosen to deviate from true Islamic teachings altogether for the 
sake of so-called modernity. For the former, television programs for example, are seen as a method to control the minds of young Muslims by Western non-believers. In Malaysia, a program called Reflections tries to turn this belief on its head and it uses the modern electronic medium of television to spread the universal values of Islam through original program concept, content and medium of delivery. As it is targeted at the 13-24 age group, Reflections was at the cutting edge of popularizing universal Islamic ideals especially in the younger section of Malaysian society. An empirical and original research was thus conducted to answer two major research questions as outlined below:

First, employing discourse analysis and by textually and thematically analyzing actual excerpts of script from all the segments of Reflections, what message is being presented to the audience and what image is being reflected of Islam as a religion with universal and positive human values?

Second, what do key members of the production team have to report about the thinking, planning and decision making behind the concept, content and medium of Reflections, as a contemporary television magazine program that is based on the ideals of Islam as a major world religion?

\section{Methodology of the research}

An empirical and original research was conducted, employing mixed-mode methodology to study; (1) actual materials from a television series called Reflections in the form of television scripts from three segments in the show and relate this back to the ideal of universal and positive Islamic values; (2) the thinking and decision making process behind Reflection's program concept, content and medium as related to the ideals of Islam as a world religion and as captured by the Malaysian government's national policies.

\subsection{The site of study}

This research effort studied the program concept, content and medium of delivery of a television program called Reflections produced by the Islamic Development Department of Malaysia (JAKIM). This study was conducted almost entirely at the JAKIM television studio in Putrajaya, the administrative capital of the Malaysian government, located outside of the business and national capital of Kuala Lumpur. The studio is located within JAKIM's Putrajaya office on the first floor. The research site also included the post-production studio of RTM, the Malaysian National Radio and Television network located near the heart of Kuala Lumpur. However, given the main focus of the study is on the thinking behind Reflections, the JAKIM Putrajaya office became the base for research, after ethical issues of access and security were cleared with JAKIM early in the research cycle.

\subsection{Research participants}

The research participants were made up of personnel working as the production team of Reflections. After permissions were sought (and granted either verbally or in writing or both), research participants made up of key members of the production team who have direct control on the thinking, planning and decision making behind the concept, content and medium of delivery of Reflections were 'shadowed' and interviewed. Several open-ended interview sessions were conducted with firstly the Director of Programming at JAKIM to learn about the concept of Reflections. This was followed by the Producer of the series to learn about the program content and also the Director of the series, who provided input about the medium and delivery of this television program. The Assistant Producer and the Assistant Director were also interviewed in depth to ensure that the qualitative data collected was more than adequate for analysis and to give a clearer vision of reality.

\subsection{Design of the research}

As explained in the preceding section two modes of data collection were employed in this study, to increase the validity and reliability of data whilst lessening the possibility of bias (Denzin and Lincoln, 1994). The first data group is textual data from the actual production scripts that have been written for Reflections. The second is data gathered from the open-ended interviews with the production team. The first data group was easily collected given that I only needed to seek permission to examine them for this academic research. Nevertheless, interviewing members of the production team did represent a real challenge given their tight and time sensitive working schedule and this was the reason why the interviews were only conducted with five key individuals, instead of all the production crew.

For the collection of textual data, I started by seeking permission to examine excerpts of actual scripts from Reflections in this study from JAKIM and then I accessed all of the episodes that have gone through post-production so far (currently 20 episodes have been produced although not all have been aired by RTM, the national broadcaster). The textual data collected was then analysed using three discourse analysis methods namely study of textual surface features, study of thematic organisation and measure of word use and frequency that could be employed to study facets of the mass media (see Talbot 2007; Woods, 2007). 
For the interview sessions with members of the production team, five lead-in questions were posed to all research participants. This was followed by several lead-off questions in line with these three themes - program concept, program content, program medium and delivery - as related to the job scope of that particular individual. Although open questions were employed, interview sessions were limited to around 60 minutes only given the complexities of transcribing spoken data. Interviews were held mainly in English, although the national language Bahasa Malaysia was also used by the participants, which was typical of Malaysian English (or Malenglish/Manglish) users. The sessions were recorded if the participant agreed, or if she or he did not dictation notes were collected by the researcher. For verification purposes, recordings and the notes were then shared with the participants, to increase the accuracy of the data before further analysis by the researcher.

\section{Data presentation and analysis}

\subsection{Textual data from the written televisions scripts of the program}

The textual data collected was analysed using three discourse analysis methods namely study of textual surface features, study of thematic organisation and measure of word use and frequency.

\subsubsection{Textual surface features}

The overall impression after several surface readings of all the scripts of Reflections is that they could as well be any other typical television lifestyle or television magazine program. The words used were non technical except for the second segment of the show that covers science and technology issues, from an Islamic point of view. The first and third segments were oftentimes 'chatty' akin to a dialogue between presenter and audience (this was especially true of the third segment) and quite informal. The first and second segments used mainly reported speech, whilst the final segment was mainly written in the first person present tense conveying again the idea of the audience talking to the presenter and vice versa and creating a sense of immediacy.

The overall script for each show is also quite short perhaps to give room for pre-recorded video segments and montage as written in the production notes accompanying the scripts. The longest script is only about 1,500 words long and the shortest one being around 1,300 words. The longest segment for each script seems to be the first segment called 'Youth Vibes' that presented audience with youth activities around Malaysia and interestingly it covers not just activities by Muslim youths but also youths from other races and religions. Nearly all these activities were connected to the lives of local university and college students. The shortest segment is almost always the second one called 'Islam and Science'. It is incidentally the only part of the show that uses technical jargon and words and ideas that are directly connected to the Islamic religion. As for the third and final segment 'Wise Up', it is more of a didactic and motivational slot to convey certain contemporary issues like healthy living, study skills and civic related issues.

\subsubsection{Thematic organisation}

Key themes that could be derived from analysing the texts of all the scripts in the series are: Malaysian youth issues, Islam as a religion of knowledge, living a balanced and healthy life, inculcation of universal Islamic values and the need to contribute to one's community and society. These main themes were present in all of the scripts for Reflections, although some were highlighted more often than others. Several sub-themes were also observed, for example life and living in a multicultural society, the sharing of knowledge with all Malaysians and the importance of intercultural understanding between Muslims and non-Muslims in the Malaysian context.

Interestingly enough, for an Islamic television program sometimes the themes covered within the scripts of Reflections were not directly related to spreading the message of Islam per se. The theme of Islam and knowledge development was purely academic and not preachy with clear focus being given to scientific discoveries and technological advancements. On the other hand, in some episodes of the television series religious scriptures from the Holy Quran were quoted and translated to link between Islam and science, but in the main religion is but one of several main unifying themes used to organise the series. Living a balanced, healthy, productive and safe life is arguably the theme that was given the most focus in all the scripts followed by purely academic discussions of universal norms and values that are related to Islam.

\subsubsection{Measure of word use and frequency}

A phrasal frequency method was employed to find utterances like 'Islam', 'Muslim', 'The Prophet', 'Al-Quran', actual excerpts from the Holy Quran, actual excerpts from the Hadith (or teachings) of the Holy Islamic Prophet Muhammad, and other interesting linguistic and extra-linguistic features related to the Islamic religion and way-of-life as they occur in all the scripts. Again, nearly all of the time these religiously loaded words were only found in the second segment of the television program 'Islam and Science'. Even then, it was difficult to find all of the above words and phrases appearing in an episode except for episodes nine and ten of the first season with 
extensive discussions that relate Islam to current scientific thinking.

The highest frequency of words were 'life', 'lifestyle', 'youth', 'young' and 'value', notwithstanding articles, pronouns, verbs and other functional words and phrases. This illustrates perhaps the ideals espoused by the production team of the series that Reflections should be a vehicle for sharing positive and universal Islamic values with every Malaysian regardless of social background and not merely as a religious show meant for devout Malaysian Muslims.

\subsection{Interview data from key production personnel of the television series}

Three research themes namely program concept, program content and program medium and delivery, made up the core of my qualitative open-ended interviews. The Director of Programming gave much input on the concept of Reflections. This was followed by the Producer of the series who reported on the program content and also the Director of the series, who provided input about the medium and delivery method of this television program. The Assistant Producer and the Assistant Director also gave their comments on all of these research themes. It must also be mentioned that although the interviews were related to specific job scopes, all the research participants commented on the three research themes based on their experience in producing Reflections. Noteworthy excerpts from the interview sessions are presented below.

\subsubsection{Interview data, program concept}

According to the Director of Programming, this television program is unique because it is "informal, casual and very much like a conversation between friends". The series presenter for example, was told not to wear typical Islamic looking attire but was asked to dress in informal Western attire. She added that this was to:

"Help give the image of a modern religion [and] being open to new things as long as it's within boundaries. It [Islam] is not just a serious religion all the time so we cannot have fun like other people or to dress so strange".

This idea was supported fully by the Producers and Directors. They also felt that an open program concept and a more relaxed approach could give the image of a progressive and non oppressive religion. The Assistant Producer made a very interesting comment:

"CNN, BBC, all they show [are] Muslim[s] with machineguns, Muslim terrorists. Itu salah [trans. that is untrue], Westerns [sic] always do that. Now we try to show to people the real Islam religion starting with a normal person [the presenter]".

However, the Director of Programming also mentioned that Malaysia and other Muslim majority countries should not just produce television shows without Eastern value "like all the Hollywood stories, just because we want to show Islam is modern". The Director believes that the open and non-stereotypical programme concept:

"Will help to share good things [with] all the people in Malaysia, not just Islamic peoples [sic]". Lagi pun [trans. In fact] this program is just basically a magazine show only, so everyone must watch it to get new information on life and other things. It is about contemporary lifestyle for everybody not just Islamic people".

5.2.2 Interview data, program content

For the Producer and Assistant Producer of Reflections, it was generally not easy for them to think about what to prepare for the program week after week. At last they decided to focus on youth activity and a healthy lifestyle as the main focus. The Producer added:

"We also wanted to talk about Islam so we came up with a segment called Scientific Islam that we changed the name later. Science is very important in Islamic because it is learning. Islam always supporting [sic] learning".

Nevertheless, on this matter the Director of Programming mentioned that from her experience, coming up with Islamic related content was always easy but "how we present to people is hard, we don't want to give just a khutbah [sermon] only". Perhaps this is true but at the same time nearly all of the research participants also mentioned that they cannot sacrifice Islamic and central religious content just to make the show look more modern and moderate. The Assistant Director made a succinct point:

"We must balance religion and other issues [but] we always have to focus more on religion like the Prophet said but it doesn't also mean we have to be too extreme [conservative] all the time".

This ideology forms the basis of Islamic television programs according to the Programming Director, but she also believes that at this moment in time, the electronic media in Malaysia still lacks experience in balancing 
between religious and social issues. According to her, "they all [producers] that I know always choose left or right only, they all cannot stay in the middle way".

\subsubsection{Interview data, program medium and delivery}

The medium of this television program is perhaps the most interesting selling point of Reflections as the English language is by tradition the language of choice by non-Muslims in Malaysia. The Director believes that:

"This way people who are not Malay [Muslims] can also watch the show and learn something about Islam, the positive ones not negatives, also they can see that we [Muslims] can live we everyone [...] We are very peaceful also the program is in English so we [Muslims] don't hate all the Western things".

On this matter, I asked all the research participants whether they though that what they were doing amounts to brainwashing the public - the answer was a resounding "No", from all of them. According to the Director:

"How come we brainwash when we don't say become [convert to] Islam or anything? We don't say your religion is bad, you are wrong or we attack all other people. All we say is Islam and knowledge are both important because it is a religion of learning things and also Islam is peace [...] If we want just to present to Muslims we will use BM [Bahasa Malaysia or Malay, the national language] only, no need for English right?"

The research participants also thought that the program delivery through the television medium is the way forward for Muslim majority nations like Malaysia, because nowadays nearly all Malaysians have access to the box. The medium is also very powerful because as the Assistant Director observed, "today on TV, you can see and hear [that] makes you understand very quickly you know, if you just read or listen you cannot understand well".

On the contrary, some of the research participants think that the slot given for the show is too short compared to other non religious programs, for example entertainment shows or other lighter infotainment-type programs. According to the Director:

"We are lucky because the PM always support [sic] us, so we can use TV to deliver programs. Some countries don't have this because many Muslim countries sometimes are poor, [in] some countries their government also don't follow the Islamic [way of] life so they always have no chance to learn Islamic teachings."

\section{Discussion and conclusion}

To conclude, this study managed to find out how a contemporary Islamic magazine made-for-television program, tries to deliver a message of peace and understanding to Malaysians from all walks of life, based on positive and universal values derived from the teachings of Islam. On the other hand, for the future it would also be more helpful to collect data from the actual audience of such programs to provide a more complete picture of reality. It would be extremely beneficial for us to know for example, what a section of the target audience actually think of such a program and how do they perceive the program in terms of its concept, content and medium as related to the idea of popular Islam? Due to the double constraint of resource and time, I was not able to collect this data set for this current study.

That said, from the limited depth of the textual and interview data collected, we could learn much about the use of the electronic media to develop human capital by spreading the universal values and positive ideals of one religion (in this case Islam) across a common platform that is life experiences and living. Whether it was didactic in the process of delivering the message, whether or not the message went through to the intended recipients did not deter from the fact that such a bold initiative challenges not just the stereotype of Islam espoused by the Western world, but it also forces Muslims in this country to adopt a more encompassing world view of the physical world around them. Instead of just seeing religion as one's personal accountability to one's Creator, an initiative like Reflections could compel Muslims to comprehend the concept of religion as a way of life and not to constraint it.

With more television programs such as this that tries to find ideals and values that could be commonly shared regardless of skin tone or religious creed, perhaps in the long run people in Muslim majority countries like Malaysia, would be able to cherish their differences and truly respect each other for things that they share in common. In the process, modern-day Islamic television programs like Reflections would also be able to reflect unto the world the true face of Islam as a religion that preaches knowledge, learning, peace, understanding and above all else - to help counter the negative picture of this world religion that has been painted by some who seem to be preaching tolerance and religious freedom, but are more likely to be fanatical troublemakers and 
uncompromising zealots.

\section{Acknowledgement}

A shorter version of this empirical research paper was presented at the inaugural Regional Conference on the Humanities, 18-19 February 2009, in the state of Perak, Malaysia.

\section{References}

Abu-Lughod, L. (1993). Finding a place for Islam: Egyptian television and the national interest. Public Culture, $5,3,493-513$.

Adamu, A. U. (2006). Transglobal media flows and African popular culture: Revolution and reaction in Muslim Hausa popular culture. London: School of African and Oriental Studies (Mary Kingsley Zochonis lecture for the African Studies Association).

Baig, K. (2003). Islam and Television: Understanding television. [Online] Available: http://www.albalagh.net/general/tv.shtml (December 23, 2008).

Berita Nasional Malaysia (BERNAMA). (2007). A good 15 years for IKIM. [Online] Available: http://www.ikim.gov.my/v5/index.php?lg=2\&opt=com_article\&grp=1\&ssec=\&key=1207\&cmd=reset all (November 3, 2008).

Camroux, D. (1996). State responses to Islamic resurgence in Malaysia: Accommodation, co-option, and confrontation. Asian Survey, 36, 9, September, 852-868.

Demographic Institute. (1999). Baseline Survey of Young Adult Reproductive Welfare in Indonesia 1998/1999. Jakarta: The Demographic Institute, Faculty of Economics, University of Indonesia.

Denzin, N. K. \& Lincoln, Y. S. (1994). Entering the field of qualitative research. In N. K. Denzin \& Y. S. Lincoln (Eds.) Handbook of Qualitative Research. California: Sage.

Government of Malaysia. (2000). Knowledge Based Economy Master Plan Policy Paper. Kuala Lumpur: Malaysian Government Printers.

Hamid, J. (2007). Malaysian leader steps up drive for moderate version of Islam. [Online] Available: http://www.reuters.com/article/sphereNews/idUSSP967520070316? sp=true\&view=sphere (November 2, 2008).

Hussain, M. (2000). Islam, media and minorities in Denmark. Current Sociology, 48, 4, 95-116.

Jabatan Kemajuan Islam Malaysia (JAKIM). (2006). About JAKIM. [Online] Available: http://www.islam.gov.my/english/jakim.html (November 23, 2008).

Jones, E. (1995). The price of information. National Interest, 41, 82-92.

Kling, Z. (1995). The Malay family: Beliefs and realities. Journal of Comparative Family Studies, 26, spring, 43-66.

Launay, R. (1997). Spirit media: The electronic media and Islam among the Dyula of Northern Cote d'Ivoire. Africa: Journal of the International African Institute, 67, 3, 441-453.

Lorenzo-Dus, N. (2009). Television discourse: Analysing language in the Media. Basingstoke: Palgrave Macmillan.

Malashenko, A. \& Vale, M. (2000). Islam in Russia: Notes of a political scientist / tr. by M. Vale. Russian Social Science Review, 41, 6, 57-65.

Norton, A. R. (2003). The new media, civic pluralism, and the struggle for political reform. In D. F. Eickelman and J. W. Anderson (Eds.) New media in the Muslim world: The emerging public sphere (2 ${ }^{\text {nd }}$ edition), Bloomington, IN: Indiana University Press, 19-32.

Paietta, A. C. (2005). Saints, clergy, and other religious figures on film and television, 1895-2003. Jefferson, NC: McFarland \& Co.

Roff, W. R. (1998). Patterns of Islamization in Malaysia, 1890-1990s: Exemplars, institutions, and vectors. Journal of Islamic Studies, 9, 2, 210-228.

Talbot, M. (2007). Media discourse: Representation and Interaction. Edinburgh: Edinburgh University Press.

Timmerman, C. (2000). Secular and religious nationalism among young Turkish women in Belgium: Education may make the difference. Anthropology \& Education Quarterly, 31, 3, 333-54.

Whine, M. (2005). The advance of the Muslim Brotherhood in the UK. In H. Fradkin, Haqqani, H. \& Brown, E. 
(Eds.) Current Trends in Islamist Ideology (vol. 2). Washington DC: Hudson Institute, 30-40.

Woods, J. (2007). Democracy and the press: A comparative analysis of pluralism in the international print media. The Social Science Journal, 44, 213-230.

Yamani, M. (2003). Saudi Arabia: The Arab street, the media and popular agitation since September 11. Asian Affairs (London), 34, 2, 143-7. 